Institute of $\mathbf{F}_{\text {ood and }} \mathbf{A}_{\text {gricultural }} \mathbf{S}_{\text {ciences }}$

\title{
2003 Handbook of Employment Regulations Affecting Florida Farm Employers and Workers: Farm Labor Contractor Registration and Testing [State] ${ }^{1}$
}

\author{
Leo C. Polopolus, Michael T. Olexa, Fritz Roka, and Carol Fountain ${ }^{2}$
}

\section{Purpose}

To establish state standards and registration procedures for farm labor contractors (crew chiefs) operating in the State of Florida.

\section{Who Must Register}

A Farm Labor Contractor Registration certificate is required by any individual who:

- For a fee or other valuable consideration, recruits, transports into or within the state, supplies, or hires, at any one time in any calendar year, one or more farm workers to work for or under the direction, supervision, or control of a third person.
- Recruits, transports into or within the state, supplies, or hires, at any one time in any calendar year, one or more farm workers and who, for a fee or other valuable consideration, directs, supervises, or controls all or any part of the work of such workers.

\section{Program Requirements}

Labor contractors must do the following:

- Annually apply for and obtain a certificate of registration from the Department of Business and Professional Regulation. Renewals will be in the birth month of the crew leader or on the date of incorporation if the applicant is a corporation.

1. This is EDIS document FE397, a publication of the Department of Food and Resource Economics, Florida Cooperative Extension Service, Institute of Food and Agricultural Sciences, University of Florida, Gainesville, FL. Published July 2003. This information is included in Circular 1200, Handbook of Employment Regulations Affecting Florida Farm Employers and Workers. First published February 1992 as Circular 1043. Revised December 2002 as Circular 1200. Please visit the EDIS website at http://edis.ifas.ufl.edu.

2. Leo C. Polopolus, Professor Emeritus, Department of Food and Resource Economics, University of Florida, Gainesville, FL; Michael T. Olexa, Professor, Department of Food and Resource Economics, University of Florida, Gainesville, FL; Fritz Roka, Associate Professor, Department of Food and Resource Economics, Southwest Florida Research and Education Center, Immokalee, FL; and Carol Fountain, Assistant Editor, Department of Food and Resource Economics, University of Florida, Gainesville, FL; Florida Cooperative Extension Service, Institute of Food and Agricultural Sciences, University of Florida, Gainesville, FL.

This document is designed to provide accurate, current, and authoritative information on the subject. However, since the laws, administrative rulings, and court decisions on which it is based are subject to constant revision, portions of this publication could become outdated at any time. This publication is distributed with the understanding that the authors are not engaged in rendering legal or other professional advice, and the information contained herein should not be regarded as a substitute for professional advice. For these reasons, the utilization of these materials by any person constitutes an agreement to hold harmless the authors, the Institute of Food and Agricultural Sciences, and the University of Florida for any liability claims, damages, or expenses that may be incurred by any person as a result of reference to or reliance on the information contained in this publication.

The Institute of Food and Agricultural Sciences is an equal opportunity/affirmative action employer authorized to provide research, educational information and other services only to individuals and institutions that function without regard to race, color, sex, age, handicap, or national origin. For information on obtaining other extension publications, contact your county Cooperative Extension Service office. Florida Cooperative Extension Service/Institute of Food and Agricultural Sciences/University of Florida/Christine Taylor Waddill, Dean. 
- Pay a nonrefundable fee (\$75.00) for filing an application for a Certificate of Registration.

- Carry his or her certificate of registration at all times and produce or display the certificate to all persons with whom he or she plans to deal as a farm labor contractor.

- Promptly pay monies due workers and semi-monthly or at the time of payment present each worker with a completed Notice of Payment which should include the amount and rate of compensation, the number of hours worked, the employer's name, the employer's federal employment identification number, and a detailed itemization of all deductions from each worker's wages.

- Prominently display in English and Spanish, if necessary, at the workplace and in vehicles used to transport workers:

1. A copy of his or her statement of working conditions (LES Form LET 3103). (This form is not required if federally required form WH-516 is already posted.)

2. A statement indicating the rate of compensation he or she receives from the grower and what rate he or she is paying the workers (LES Form ESF 3101).

- Provide liability insurance coverage on all vehicles used to transport workers in an amount at least equal to that provided by the financial responsibility laws of Florida.

- Submit proof that each vehicle used to transport farmworkers is in compliance with the vehicular safety standards of the state in which the vehicle is registered.

- Provide Workers Compensation coverage for all workers, unless exempt under agricultural small employer status.

- Furnish the Department of Business and Professional Regulation with a set of his or her fingerprints.
- Retain, for three years, a copy of each Notice of Payment and other required payroll information. Applicant should be prepared to provide copies of payroll receipts or check stubs if requested by the registering agency.

Note: Unlike MSPA, the State Act does not have a provision for a Farm Labor Contractor Employee Certificate. Therefore, any individuals performing contractor activities in Florida must register as a contractor under the State Act even though they have an Employee Certificate under MSPA.

\section{Labor Contractor Test}

Applicants for a Certificate of Registration must take a written or oral examination, in the language of the applicant, which demonstrates his or her knowledge of the duties and responsibilities of a farm labor contractor. A \$35 fee will include the test and educational materials. This will be a one-time test, except that the Department of Business and Professional Regulation (DBPR) may require an applicant for renewal of the Certificate of Registration to retake the test if:

- During the prior certification period the DBPR issued a final order assessing a civil money penalty or revoked or refused to renew or issue a Certificate of Registration.

- The DBPR determines that any change in the duties and responsibilities of farm labor contractors necessitates a new test. In this situation, all applicants for renewal would be required to be retested.

\section{Exclusions}

The Florida Farm Labor Contractor Registration Law does not apply to:

- Any person, or an immediate family member of such person, who is the owner or lessee of a farm or who is the owner or lessee of a packinghouse or food processing plant and who employs workers in planting, cultivating, harvesting, or preparing agricultural products for delivery to such packinghouse or food processing plant. 
- Any person who transports workers solely by means of a car pool.

\section{Additional Information}

- Chapter 450, Part III, Florida Statutes

- Rule 38H-11, Florida Administrative Code

\section{Responsible Agency for Registration}

Florida Department of Business and Professional

Regulation

Division of Professions

Post Office Box 1698

Tallahassee, FL 32302-1698

(850) 488-3131

http://fcn.state.fl.us/dbpr

\section{Responsible Agency for Compliance and Enforcement}

Florida Department of Business and Professional

Regulation

Division of Professions

Post Office Box 1698

Tallahassee, FL 32302-1698

(850) 488-3131

http://www.state.fl.us/dbpr/pro/farm/compliance/ farmlabor.index 